УДК 373.3.015.31:7

DOI:

Олександр Плахотський, стариий викладач кафедри природничо-математичних дисциилін та інформатики у початковій освіті Донбаського державного педагогічного університету

\title{
ВПЛИВ МИСТЕЦТВА ТА ДІЙСНОСТІ НА РОЗВИТОК ЕСТЕТИЧНИХ ПОЧУТТІВ ДІТЕЙ МОЛОДШОГО ШКІЛЬНОГО ВІКУ
}

У статті висвітлюються найбільш дієві засоби естетичного виховання молодших школярів, а саме, мистеитво і дійсність. У контексті иієї взаємодії визначаються особливості впливу мистеитва на естетичний розвиток школяра в залежності від особистого загального розвитку, рівня освіти, занять певним видом мистечтва та ін. Розкривається зміст і умови педагогічного керівництва процесом розвитку естетичного сприйняття дійсності через певні види і жанри мистецтва. Визначаються педагогічні засоби i методи, за допомогою яких формується естетична діяльність учнів молодшого шкільного віку.

Ключові слова: естетика; мистецтво; початкова школа; виховання; педагогічне керівництво; навчальний процес.

Jim. 10.

Oleksander Plakhotskiy, Senior Lecturer of the Natural and Mathematical Sciences Disciplines and Informatics in the Elementary Education Department Donbass State Pedagogical University

\section{THE INFLUENCE OFART AND REALITY ON THE DEVELOPMENT OF AESTHETIC FEELINGS OF PRIMARY SCHOOLCHILDREN}

The article deals with one of the essential problems of the aesthetic education of younger generation. The development of aesthetic feelings of primary schoolchildren depends more on the choice of optimal, multifaceted and concentrated and influential on all personal qualities of a student by means. It is noted that one of these means is the influence of various types of art and reality, which is reflected in it in a certain way, on students, their holistic interconnection in the system of aesthetic education.

It is also noted that, unfortunately, in our time, the practice of aesthetic education is far behind the scientific and educational and social level of the schoolchildren's development, which creates certain difficulties in solving the problems and harmonious development of the individual. Thus, the relevance of the topic is to identify and develop the effective methods of influencing of art and reality on the development of aesthetic feelings of primary schoolchildren.

The aim of the article is to highlight the psychological and pedagogical and cultural conditions of development and implementation of these methods into the educational process of primary schoolchildren.

The methodological basis of the research is the thesis about the dialectical connection between the art and reality and its influence on the social and psychological development of the individual. It is noted that works of art integrate in themselves various directions of aesthetic development of reality, and therefore have multifaceted opportunities for the formation of ideals, feelings, thoughts, aspirations.

Focusing on mastering of different types of art, the school system of aesthetic education uses the traditional three main types for studying: literature, fine arts and music. The choice is traditionally justified and argued. But, according to research, the greatest effectiveness is achieved in the bilateral interaction of art with reality. And it is more widely achieved in the extra-curricular and extra-lessons forms of educational work.

In the context of this interaction, the peculiarities of the art influence on the aesthetic development of a schoolchild are revealed depending on personal general development, the level of education, engaging a certain kind of art, etc. The content and conditions of pedagogical management of developing aesthetic perception of reality through certain kinds and genres of art are revealed. Pedagogical means and methods which develop the aesthetic activity of primary schoolchildren are described.

Keywords: aesthetics; the art; a primary school; an education; pedagogical management; an educational process.

A ктуальність проблеми. Виробнича та духовна сфери життя являють собою дві тісно пов'язані між собою форми існування людини. Вони активно впливають одна на одну і в той же час суттєво відрізняються певним чином одна від одної. Продуктом виробничої сфери є конкретні матеріальні речі, продуктами ж духовної сфери є естетичні форми, які матеріалізуються у мистецтві, у спілкуванні, у відношенні між людьми та відношенні людини до навколишньої дійсності. Порушення балансу між цими сферами негативно впливає на розвиток 


\section{ВПЛИВ МИСТЕЦТВА ТА ДІЙСНОСТІ НА РОЗВИТОК ЕСТЕТИЧНИХ ПОЧУТТІВ ДІТЕЙ МОЛОДШОГО ШКІЛЬНОГО ВІКУ}

конкретного людського буття, так і на розвиток суспільства в цілому. Відчуження від культурних цінностей, зниження моральних критеріїв, нівелювання загальнолюдських норм поведінки утворюють значні проблеми при формуванні життєвої позиції людини.

Педагогіка, психологія, культурологія стверджують, що формування естетичного відношення до світу й навколишнього життя закладається 3 самого народження дитини і 3 часом активно розширює межі поля свого впливу, охоплюючи нові й нові сфери людського бугтя [8]. Одне з ключових місць у цьому процесі посідає молодший шкільний вік. У процесі шкільної навчально-пізнавальної діяльності здійснюється специфічне формування естетичних почуттів як через систему спеціальних виховних заходів, так і в контексті вивчення навчальних предметів.

Розвиток естетичних почуттів молодших школярів більшою мірою залежить від вибору оптимальних, максимально економічних у часі, $\mathrm{i}$ в той же час багатогранних і концентровановпливових на усі особистісні якості школяра, засобів. Одним з таких засобів $є$ вплив різних видів мистецтва на учнів, їх цілісний взаємозв'язок в системі естетичного виховання. "Мистецтво $€$ могутнім засобом виховання естетичного відношення до дійсності. Воно відображає в художньому образі принципово новий рівень дійсності, виступає як універсальний засіб бачення світу очима іншої людини, перетворення зовнішніх культурних сенсів у світ особистості" $[1,212]$.

На жаль, у наш час практика естетичного виховання значно відстає від науковоосвітянського рівня розвитку школярів, що створює певні труднощі у вирішенні задач гармонійного розвитку особистості.

При всій значущості мистецтва у формуванні нової людини, школа ще не використовує в повній мірі нічим не замінні можливості духовного впливу на підростаюче покоління, і особливо мистецтва. У результаті, на думку вчених, виник суспільний прошарок, що засвоїв зовнішні ознаки цивілізації, але позбавлений елементарних уявлень про справжню культуру [4].

Отже, актуальність теми полягає у виявленні і розробці ефективних методів впливу мистецтва та дійсності на розвиток естетичних почуттів дітей молодшого шкільного віку.

Мета статті полягає у висвітленні психологопедагогічних та культурологічних умов у розробці й впровадженні зазначених методів у навчальновиховному процесі молодших школярів.

Аналіз основних досліджень і публікацій.
Питанню естетичного виховання школярів засобами мистецтва присвятили свої дослідження відомі педагоги, такі як К. Ушинський, Я. Коменський, Й. Песталоцці, А. Макаренко, В. Сухомлинський. Значний внесок у дослідження зазначених питань внесли й сучасні вчені. Зокрема, А. Федь досліджував специфічні шляхи естетичного виховання школярів на уроках 3 основ наук, у тому числі й засобами мистецтва. Філософські проблеми естетичного виховання засобами мистецтва досліджували М. Каган, С. Кримський, та ін. Питання формування екологічної культури молодших школярів засобами мистецтва досліджував І. Павленко, О. Костюк досліджував питання про роль музичного мистецтва в розвитку художньої культури дітей. Проблему естетичного виховання й естетичної освіти школярів досліджували О. Алексійчук, Л. Коваль, А. Роздимаха та ін. Теоретичні основи естетичного виховання засобами мистецтва розробляли відомі спеціалісти в галузі естетики і діячі мистецтва: Л. Гаврилова, І. Гончаров, О. Костюк, Д. Кабалевський та інші.

Виклад основного матеріалу. Керувати формуванням різнобічно розвиненої особи треба на всіх етапах життя людини. Вирішальне значення має це в шкільні роки, коли закладаються основи естетичного світосприймання, формуються художні смаки, оцінки, ідеали. Естетичне виховання залежить від рівня загального розвитку особистості, їі віку й характеру сприймання, засвоєння нею морально-естетичних ідеалів людства.

У процесі засвоєння людиною суспільних цінностей встановлюється зв'язок іiі 3 суспільством завдяки критичній нормі естетичних почуттів і особливостям розуміння їх. Діяльність учнів свідчать про характер уявлень дітей про цінності, їх спрямованість.

Залежно від рівня розвитку естетичних почуттів, досвіду розуміння мистецтва людина сприймає в структурі естетичної інформації та відомості, які відповідають усвідомленим переживанням, і ті, які впливають на неї емоційно, на рівні інтуїції. I в цьому сенсі універсальним джерелом естетичної інформації $\epsilon$ мистецтво. Як зазначає I. Павленко, “Твори мистецтва інтегрують у собі різні напрями естетичного освоєння дійсності, а тому й мають багатогранні можливості для формування ідеалів, почуттів, думок, прагнень" $[7,8]$. Усе це вимагає добору найбільш значущих для норми естетичної діяльності знань, визначення їх в програмах для загальноосвітньої школи 3 літератури, образотворчого мистецтва і музики навичок й 


\section{ВПЛИВ МИСТЕЦТВА ТА ДІЙСНОСТІ НА РОЗВИТОК ЕСТЕТИЧНИХ ПОЧУТТІВ ДІТЕЙ МОЛОДШОГО ШКІЛЬНОГО ВІКУ}

умінь. Таким чином, учнів підводять до розуміння нормативної естетичної діяльності, робота над якою практично охоплює весь матеріал предметів естетичного циклу і властива для кожного його етапу засвоєння.

Орієнтуючись на засвоєння різних видів мистецтва, шкільна система естетичного виховання використовує для навчання учнів традиційних три основних види - літературу, образотворче мистецтво і музику. Вибір поки що виправданий i аргументований. Ці види мистецтва мають багату історію розвитку, величезну кількість пам'яток неперехідної естетичної цінності.

У процесі спілкування дитини 3 мистецтвом виявляється рівень розвитку індивідуальної здатності сприймати твори мистецтва, а також відбувається перенесення умінь і навичок на оцінювання естетики природи, суспільних явищ, поведінки людини. Уміння та навички, набуті у процесі оцінювання одного мистецького твору, переносяться на аналіз складнішого твору, забезпечують його сприймання на вищому рівні образного узагальнення й оцінки [6].

Специфіка естетичної діяльності полягає в тому, що в ній наявний елемент творчості. Завдяки здатності переноситись в атмосферу художнього твору, співпереживати, засвоювати його ідеї, дитина дістає можливість жити одним життям $з$ героями художніх творів, підкорятись тому почуттю насолоди, яке супроводжує сприймання високого мистецтва.

Відомий педагог і композитор Д. Кабалевський зазначав, що “Людині властиво сприймати світ, найрізноманітніші життєва явища крізь призму естетичну, що без сумніву, пов'язане з вродженою в народі - здатністю, а можливо, правильніше б сказати, з потребою естетичної діяльності" [3, 44].

Психолого-педагогічні дослідження щодо впливу на дітей різного віку окремих видів і жанрів мистецтва, торкаються й питань формування естетичних почуттів. Вивчаючи особливості дітей молодшого шкільного віку, деякі автори вказують, що в цей період уже формуються соціальні почуття дитини, які виявляються у бажанні бути самостійною в діях і судженнях. Зазначається, що в молодшому шкільному віці особливого значення набуває педагогічне керівництво процесом розвитку різних видів діяльності, серед яких естетична діяльність посідає чільне місце. Створюються умови для дальшого розвитку естетичних почуттів, смаків, оцінок [5].

У молодших школярів легко викликати любов до співу і слухання музики. Учні перших класів уже мають невеликий активний музичний “багаж”, але не можуть розповісти про музику. Організований процес розвитку потреб у спілкуванні з творами мистецтва доводить, що учні початкових класів сприйнятливі до різних форм і методів естетичної діяльності в будь-якому виді мистецтва. При цьому слід мати на увазі розвиток спеціальних умінь і навичок за допомогою різноманітних засобів виразності.

Процес розвитку сприймання творів, зокрема, образотворчого мистецтва, сюжетної картини молодшими школярами проходить три стадії. I. Гончаров визначає їх як стадії перерахунку, опису і тлумачення. Він підкреслює залежність цих стадій від змісту картини, методів роботи над нею й існування в учнів емоційного та інтелектуального багажу. Часто трапляється, що увагу молодших школярів привертають дрібниці які істотного значення для твору не мають [2].

Естетична діяльність, що виникає в людини, пов'язана 3 особливостями розвитку ii сприймання і досвіду емоційного ставлення до окремого виду мистецтва, здатністю виявляти людські почуття. Дослідники вважають, що виховання потягу до прекрасного пов'язане 3 відчуттям міри, пропорції, гармонії [5], [9].

Вивчаючи особливості естетичних ставлень, учені виділяють два важливих компоненти естетичного процесу: емоційний відгук на художній твір і раціональну його переробку, тобто вміння логічно порівнювати естетичні норми з художніми образами твору мистецтва, який сприймається [1].

Кожний період розумового розвитку людини спирається на певні види діяльності: у дошкільника - це гра і дитяча творчість, у молодших школярів провідними стають навчання і пізнавальна діяльність. Підлітковий вік і період юнацтва характеризуються активізацією ціннісноорієнтаційної діяльності, пошуку змісту життя, самостійного визначення моральних, політичних і естетичних ідеалів [3].

Естетичні почуття, погляди, ідеали, художній смак формуються в певній атмосфері (навчальновиховний процес, дозвілля дітей, засоби масової інформації). Якщо в процесі навчання вчитель може контролювати в учнів знання, уміння і навички розуміння мистецьких творів, то в нерегламентований час ці можливості досить обмежені. Отже, процес залучення школярів до естетичної діяльності потребує відповідного педагогічного керівництва.

Першою умовою педагогічного керівництва естетичною діяльністю школярів є системна організація всіх складових впливу на школярів. Вона передбачає їх оптимальне поєднання. 


\section{ВПЛИВ МИСТЕЦТВА ТА ДІЙСНОСТІ НА РОЗВИТОК ЕСТЕТИЧНИХ ПОЧУТТІВ ДІТЕЙ МОЛОДШОГО ШКІЛЬНОГО ВІКУ}

Другою умовою є створення системи аналогій, які допомагають сприймати різні види мистецтва, збагачують необхідний асоціативний фонд, що актуалізується на уроці та в позаурочний час. Аналіз художнього образу випливає з естетичних почуттів, які забезпечують емоційність і естетичну оцінку. Проте учні правильно розумітимуть твори лише тоді, коли емоційні враження їх будуть спиратись на достатньо повну інформацію про ці твори.

Третьою умовою забезпечення процесу формування естетичних почуттів в учнів $\epsilon$ збагачення й активізація їх словникового запасу, який дає можливість повно і глибоко формулювати свої думки, враження і переживання в зв'язку із сприйманням творів мистецтва.

Основними формами в розвитку естетичної діяльності $\epsilon$ навчальний процес, позакласна і позашкільна робота.

Педагогічне керівництво розвитком естетичної діяльності на уроках предметів естетичного циклу передбачає виявлення і врахування рівня розвитку дитини, мислення і здатності до естетичного аналізу, розвиток їх у навчальному процесі. Якщо дітям молодшого шкільного віку властиві емоційність сприймання, конкретність мислення, здатність до аналізу особливостей предметів і явищ, то завданням учителя є розвиток i збагачення аналітико-синтетичної діяльності, словникового запасу; тренування у визначенні кольорів, порівняння різних звучань знайомої мелодії, знаходження подібності і контрасту у визначенні явища, аналізу внутрішнього світу людини в творах художньої літератури [10].

Продовженням навчального процесу $\epsilon$ різноманітні форми позакласної роботи, в яких знання, уміння і навички стають регуляторами естетичного ставлення школярів до навколишньої дійсності, потребою самовиявлення в мистецтві. “Естетична діяльність стимулює творчу активність і виявляється в бажанні займатись конкретним видом мистецтва в гуртках, прагненні знайти оригінальні рішення під час виконання творчих робіт, внести щось самобутнє в розуміння завдань, створення музичних, літературних образотворчих творів” [1, 215]. Важливим показником естетичної активності є внесення творчих елементів в інші види діяльності школярів, перенесення засвоєних умінь і навичок на роботу учнів у літературних і драматичних гуртках, студіях музичного й образотворчого мистецтва.

Педагогічні засоби, за допомагаю яких формується естетична діяльність, повинні відповідати завданням і меті, які ставить перед собою вчитель. Їх можна об’ єднати в три основні групи:

a) ознайомлення дітей 3 художніми творами 3 метою розвитку естетичного сприймання i суджень;

б) залучення учнів до творчої роботи в різних галузях мистецтва;

в) створення відповідного естетичного оточення в сім’ї (робота з батьками) і школі.

Цей поділ цілком відповідає змісту навчальних планів і програм 3 літератури, музики i образотворчого мистецтва. Так, у початкових класах важливим матеріалом, на якому формуються естетичні почуття, $є$ опис різних часів року, що знайшли своє втілення в образних характеристиках художників, поетів, музикантів. У підлітковому віці описи природи здебільшого пов'язані 3 настроєм дійових осіб твору, їх характером і поглядами. Тому завданням учителя $\epsilon$ розкриття змісту окремих епізодів і значення опису природи в тексті усього твору, його композиції, ідейної спрямованості.

Більш впливовим твір стає тоді, коли в учнів створюються міцні асоціативні зв'язки. Допомогти в цьому можуть твори образотворчого мистецтва i музики. Важливо лише використовувати з цією метою твори, які подібні за настроєм, що сприяє поглибленню естетичного сприймання і естетичних емоцій.

Основними методами, які активізують сприймання творів в молодшому шкільному віці, можуть бути бесіда, розповідь, творчі завдання (при цьому використовуються прийоми порівняння, зіставлення, контрасту). У середньому шкільному віці до них додаються аналіз, метод аналогій, що відповідає певному виду мистецтва.

Творчу роботу учнів можна поділити на такі види: виділення головних епізодів, які сприяють засуванню основної думки твору знаходження в тексті описів, картин, за допомагаю яких розкривається основна думка, створюються художні образи; словесне малювання за уявленням в зв'язку з баченим, почутим, прочитаним знаходження висловлювань, що свідчать про авторську оцінку зображуваного в творі; підкреслення головних слів, за допомогою яких розкриваються художній образ, основна думка твору; обгрунтування свого ставлення до твору; порівняння асоціацій, які виникли в дитини, з образами твору.

В останні роки 3'явилося чимало досліджень, які розкривають специфіку формування естетичних почуттів на матеріалі книжкової графіки, літератури, пейзажної лірики. Багато 


\section{ВПЛИВ МИСТЕЦТВА ТА ДІЙСНОСТІ НА РОЗВИТОК ЕСТЕТИЧНИХ ПОЧУТТІВ ДІТЕЙ МОЛОДШОГО ШКІЛЬНОГО ВІКУ}

зроблено і в створенні методики навчання літератури, образотворчого мистецтва і музики, що дає змогутвердити про цілеспрямовану роботу над підготовкою до естетичної діяльності учнів різного віку, видаленням аспектів і особливостей формування оцінок на матеріалі цих видів мистецтва.

Естетична діяльність сприяє поглибленому розумінню перспективи розвитку, цілісному сприйманню суспільно-політичних подій, явищ художньої культури, вона $є$ також важливим компонентом розвитку творчих здібностей i обдарувань, критерієм естетичної вихованості учнів.

Отже, естетична діяльність - явище досить складне. Вона виникає в преса розвитку й удосконалення людського пізнання навколишнього світу і ставлення особистості до нього. У зв'язку 3 цим зманювались і форми вираження естетичних почуттів, сприймань, досвіту. Це положення підтверджується психологопедагогічними дослідженнями, у яких встановлюється залежність змісту естетичних почуттів від вікових і психофізіологічних особливостей дітей, а також виду мистецтва, що сприймається ними. Висновки цих досліджень дають підстави вважати, що процес формування естетичних почуттів потребує цілеспрямованого педагогічного керівництва, яке полягає в 3'ясуванні змісту і характеру естетичної інформації, якою володіють учні, та методів їі організацій; виявленні особливості сприймання й розуміння різних видів мистецтва школярами та знаходженні найвпливовіших способів керівництва цим процесом.

\section{ЛІТЕРАТУРА}

1. Гаврілова Л. Г. Проблема формування професійної компетентності майбутніх учителів музики засобами комп'ютерних технологій у теорії вітчизняної мистецької освіти / Л. Г. Гаврілова, В. І. Федоришин // Професіоналізм педагога: теоретичні й методичні аспекти: зб. наук. праць. Вип. 5. / ДВНЗ “ДДПУ”; заг. ред. проф. С. О. Омельченко; - Слов'янськ: ДДПУ, 2017. Ч. $1 .-$ С. $213-225$.

2. Гончаров И. Ф. Эстетическое воспитание школьников средствами искусства и действительности / И. Ф. Гончаров. - М.: Педагогика, 2006. - 126 с.

3. Кабалевский Д. Б. Прекрасное побуждает доброе / Д. Б. Кабалевский. - К.: Музыка, 1978. $-214 \mathrm{c}$.

4. Каган М. С. Культура - Философия Искусство / М. С. Каган, Т. В Холостова. // Эстетика. - №2. - 1988. - 324 с.
5. Коваль Л. Г. Воспитание чувства прекрасного. Метод. пособие / Л. Г. Коваль. - К.: Рад. школа, 1983. - 120 с.

6. Костюк О. Г. Сприймання музики і художня культура слухача / О. Г. Костюк. - К.: Музика, $1995,-192$ c.

7. Павленко I. Г. Формування екологічної культури молодших школярів засобами мистецтва: Автореферат дис. на здобуття наукового ступеня канд. пед. наук. (13.00.01) / І. Г. Павленко. Луганськ: - 2002. - 20 с.

8. Роздимаха А. І. Вивчення проблеми формування здатності до естетичної оцінки явищ дійсності засобами мистецтва / Професіоналізм педагога: теоретичні та методичні аспекти. - Вип. 5. - 2.1 / А. I. Роздимаха. - Слов'янськ: - 2017. C. $258-264$.

9. Попова Л. Д. Сухомлинський В. О.: Про естетичну культуру вчителя: Мотод. рекоменд. / Л. Д. Попова, К. А. Юр'єва. - Харків: ХДПІ, 1993. - $324 \mathrm{c}$.

10. Федь А. М. Нотатки на полях ненаписаного етюду. Кіноповість та два есеї. / А. М. Федь. Слов' янськ: - 2001, - С.122 - 132.

\section{REFERENCES}

1. Havrilova, L. H. \& Fedorishin, V.I. (2017). Problema formuvannia profesiinoi kompetentnosti maibutnikh uchyteliv muzyky zasobamy kompiuternykh tekhnolohii u teorii vitchyznianoi mystetskoi osvity [The issue of forming future music teachers' professional competence by computer technology tools in the theory of national art]. Professionalism of the teacher: theoretical and methodological aspects. Save sciences works. Slavyansk: DDPU Publ., vol. 5, part.1, pp. 213-225. [in Ukrainian].

2. Goncharov, I. F. (2006). Esteticheskoe vospitanie shkolnikov sredstvami iskusstva $i$ deystvitelnosti [Aesthetic education of schoolchildren by means of art and reality]. Moscow: Pedagogika Publ., 126 p. [in Russian].

3. Kabalevskiy, D. B. (1978). Prekrasnoe pobuzhdaet dobroe [The beautiful imparts the good]. Kyiv: Muzica Publ., 214 p. [in Ukrainian].

4. Kagan, M. S. \& Holstova, T. V. (1988). Kultura - Filosofiya-Iskusstvo [Culture-Philosophy-Art]. Moscow: Estetika Publ., no.2, 324 p. [in Russian].

5. Koval, L. G. (1983). Vospitanie chuvstva prekrasnogo. Metod. posobie [Beauty sense education. Method. allowance]. Kyiv: Radyanska Shkola Publ., 120 p. [in Ukrainian].

6. Kostiuk, O. H. (1995). Spryimannia muzyky $i$ khudozhnia kultura slukhacha [Perception of music 


\section{ПЕДАГОГІЧНІ УМОВИ АКТИВІЗАЦІЇ НАВЧАЛЬНОЇ ДІЯЛЬНОСТІ МАЙБУТНІХ ІНЖЕНЕРІВ-ПЕДАГОГІВ КОМП'ЮТЕРНОГО ПРОФІЛЮ}

and the artistic culture of the listener.]. Kyiv: Muzika Publ., 192 p. [in Ukrainian].

7. Pavlenko, I. H. (2002). Formuvannia ekolohichnoi kultury molodshykh shkoliariv zasobamy mystetstva [Developing primary schoolchildren's ecological culture by means of art]. Extended abstract of candidate's thesis. Lugansk, 20 p. [in Ukrainian].

8. Rozdymakha, A. I. (2017). Vyvchennia problemy formuvannia zdatnosti do estetychnoi otsinky yavyshch diisnosti zasobamy mystetstva [Studying the problems of forming the capacity to estimate phenomenon of reality by means of art].
Professionalism of the teacher: theoretical and methodical aspects. Slavyansk: DDPU Publ., vol. 5, part.1, pp. 213-225. [in Ukrainian].

9. Popova, L. D. \& Ureva, K. A. (1993). Sukhomlynskyi V. O.: Pro estetychnu kulturu vchytelia [Sukhomlynskyi V. O.: About the aesthetic culture of the teacher]. Guidelines. Kharkiv: HDPI Publ., 324 p. [in Ukrainian].

10. Fed, A. M. (2001). Notatky na poliakh nenapysanoho etiudu. Kinopovist ta dva esei. [Notes on the fields of unwritten sketch. The film and two essays.]. Slavyansk: DDPU Publ.,pp. 122-132. [in Ukrainian].

УДК 378.147

DOI:

Ольга Єсіпова, асистент кафедри педагогіки методики та менеджменту освіти Української інженерно-педагогічної академії, м. Харків

\section{ПЕДАГОГІЧНІ УМОВИ АКТИВІЗАЦІЇ НАВЧАЛЬНОЇ ДІЯЛЬНОСТІ МАЙБУТНІХ ІНЖЕНЕРІВ-ПЕДАГОГІВ КОМП'ЮТЕРНОГО ПРОФІЛЮ}

У статті розглянуто поняття “педагогічні умови”. На основі логічного аналізу, враховуючи теоретичні напрацювання науковців та педагогічний досвід визначено педагогічні умови активізації навчальної діяльності майбутніх інженерів-педагогів комп ютерного профілю, до яких відноситься зміна позиції студента в навчальній діяльності иляхом проектного підходу до ї̈ організації; мотивації в прочесі навчання иляхом інтеграції інформаційно-комунікаційних технологій в процесі навчання педагогічних дисциилін;корекція навчальної діяльності в прочесі оперативного зворотного зв 'язку.

Ключові слова: умова; педагогічні умови; активізачія навчальної діяльності; зміна позиції студента; мотивація; оперативний зворотній зв'язок.

Jim. 9.

Olha Yesipova, Assistant of the Pedagogy, Methodology and Management of Education Department Ukrainian Engineering Pedagogical Academy, Kharkiv

\section{PEDAGOGICAL CONDITIONS OF ACTIVATION OFTHE TRAINING ACTIVITY OF THE FUTURE ENGINEERS OF THE COMPUTER PROFILE}

The article deals with the concepts "conditions", "pedagogical conditions". As a result of a comprehensive analysis of the concept "conditions", one can conclude that it is a general scientific one, and its essence in the pedagogical aspect can be characterized by several provisions: the condition is the set of causes, circumstances, any objects, etc.; the designated population affects the development, education and training of a person; the impact of conditions can accelerate or slow down the processes of development, education and training, and also affect their dynamics and outcomes. The definition of the essence of the concept "pedagogical conditions" involved a number of scientists. However, there is no single definition in their interpretations. On the basis of analysis, only some of them, which are usually based on the researchers, found that in pedagogical conditions we mean a set of objective possibilities, content, forms, methods and material-spatial environment aimed at solving educational problems. On the basis of logical analysis, taking into account the theoretical developments of scientists and pedagogical experience, pedagogical conditions are formed for activating the educational activity of future computer engineers, which include the changing of the position of the student in the training activity through the project approach to organization; motivation of the learning process by integrating the information and communication technologies into the teaching of pedagogical disciplines; correction of educational activity in the process of prompt feedback.

Keywords: a state; pedagogical conditions; an activation of educational activity; changing of student position; a motivation; operational feedback.

П остановка проблеми. Сьогодні Україна зробила свідомий вибір на користь загальноєвропейської інтеграції. Входження нашої країни в цивілізоване світове співтовариство висуває нові вимоги до організації навчального процесу, навчальної 